\title{
Increased KLF5 gene expression in a Group of Turkish Gastric Adenocarcinoma Patients: Verification of HR-CGH results
}

\section{Türk Gastrik Adenokarsinomlu Hasta Grubunda KLF5 gen ekspresyonunda artış: HR-CGH sonuçlarının doğrulanması}

\author{
Bülent Aksel ${ }^{1}$, Guvem Gumus-Akay², Benan Kasapoglu ${ }^{3}$, Lütfi Doğan¹, Ajlan Tukun ${ }^{4}$, Ali Ekrem Ünal $^{5}$ \\ ${ }^{1}$ Dr Abdurrahman Yurtaslan Onkoloji Eğitim ve Araştırma Hastanesi, Genel Cerrahi Bölümü, Ankara, Türkiye \\ ${ }^{2}$ Ankara Üniversitesi Beyin Araştırmaları Uygulama ve Araştırma Merkezi, Ankara, Türkiye \\ ${ }^{3}$ Dr Abdurrahman Yurtaslan Onkoloji Eğitim ve Araştırma Hastanesi, Gastroenteroloji Bölümü, Ankara, Türkiye \\ ${ }^{4}$ Ankara Üniversitesi Tıp Fakültesi, Tıbbi Genetik Bölümü, Ankara, Türkiye \\ ${ }^{5}$ Ankara Üniversitesi Tıp Fakültesi, Cerrahi Onkoloji Bölümü, Ankara, Türkiye
}

\section{ÖZET}

GİRIŞ ve AMAÇ: Bu çalışmada mide kanserli hastalarda 13q21'de sıklıkla amplifiye bölge üzerinde yer alan KLF5 geninin ekspresyon seviyesinin tanısal ve prognostik önemini araştırmayı amaçladık.

YÖNTEM ve GEREÇLER: Gastrik adenokarsinomlu 35 hasta çalışmaya alındı ve KLF5 mRNA hem normal hem de tümörlü mide dokularında gerçek zamanlı qPCR ile belirlendi.

BULGULAR: Sonuçlarımız, KLF5'in tümör dokularında normal mide mukozası örneklerinden daha fazla aşırı eksprese olduğunu göstermiştir $(\mathrm{P}<0.01)$. Farklı derecelerde lenf nodu metastazı olan hastalarda KLF5 ekspresyonundaki değişikliğin, sınırlı istatistiksel anlamlılık düzeyinde farklı olduğu bulundu $(\mathrm{P}=0.052)$. Lenf nodu metastazlı hastalarda, düşük lenf dügüm metastazı hastalarına kıyasla, aşırı lenf nodu metastazı olan hastalarda KLF5 aşırı ekspresyonu vard1.

TARTIŞMA ve SONUÇ: Sonuçlarımız, KLF5'in gastrik tümör gelişimi ve ilerlemesindeki rolünü genişletmeye katkıda bulunabilir.

Anahtar Kelimeler: Gastrik aenokarsinom, KLF5, mRNA, prognoz

\begin{abstract}
INTRODUCTION: In this study we aimed to investigate the diagnostic and prognostic significance of the expression level of KLF5 gene located frequently on amplified region of 13q21 in patients with gastric cancer.

METHODS: Thirty five patients with gastric adenocarcinomas were enrolled in this study and KLF5 mRNA were quantified by real-time qPCR both in normal and tumoral gastric tissue samples.

RESULTS: Our results showed that KLF5 is significantly over-expressed in tumor tissues than normal gastric mucosa samples $(\mathrm{P}<0.01)$. Fold change of KLF5 expression in patients with different degree of lymph node metastasis were found to be different at a level of limited statistical significance $(\mathrm{P}=0.052)$.Patients with increased lymph node metastasis had KLF5 over-expression when compared to patients with lower lymph node metastasis. DISCUSSION AND CONCLUSION: Our results may contribute to expand the role of KLF5 in gastric tumor development and progression.
\end{abstract}

Keywords: Gastric adenocarcinoma, KLF5, mRNA, prognosis

\section{INTRODUCTION}

Gastric cancer (GC) is the third leading cause of cancer-related deaths worldwide. There is a large variation in the geographic distribution of GC. Estimated age-standardized incidence and mortality rates for both sexes showed that GC is the sixth most common type of cancer and the third leading cause of cancer-related mortality in Turkey. Although the significant advances in diagnostic techniques, surgical and chemotherapeutic approaches have resulted in a gradual decrease of GC incidence in recent 
years, it remains a major global health burden [1]. As in many cancers, GC is a biologically heterogeneous disease and both genetic and environmental factors play an important role in its etiology and progression $[2,3]$.The most common type of GC is adenocarcinoma, which can be further categorized into two main types, intestinal type and diffuse type, which are biologically different with distinct clinical and epidemiological profiles [4]. The difference in the clinic-pathological characteristics between the histological types of gastric cancer indicates that multiple genetic alterations are responsible for the development and progression of GC [2, 5].It is accepted that $\mathrm{GC}$ originates from a sequential accumulation of molecular and genetic alterations in gastric epithelial cells but the whole mechanism of carcinogenesis has yet to be clarified[6]. Numerical chromosomal abnormalities and other chromosomal rearrangements including translocations, duplications, deletions and inversions are seen in the majority of GCs and these changes may result in increase or decrease in gene expression or the generation of chimeric gene products [2]. Besides chromosomal rearrangements, small scale gene mutations leading to changes in gene expression are also associated with GC.

In recent years by using metaphase- and array-CGH techniques (m-CGH and a-CGH, respectively), different patterns of unbalanced chromosomal aberrations leading to altered gene dosage have been successfully identified in various human malignant neoplasms including GC. Mutations of tumor suppressor genes and oncogenes, such asAPC, KRAS, TP53, RUNX3, CDH1 and CTNNB1, have been frequently reported, together with amplifications of $M Y C, F G F R 2, M E T$, and $H E R 2$.Among these, gene amplification is the most common mode of genetic alterations(41\%)and frequently leads to the overexpression of genes that may affect cellular phenotype [7].Using high-resolution m-CGH, we have previously shown that the copy number gain of $13 q$ with a minimally overlapping region 13q21-q32, the locus containing the KLF5 gene, is a frequent alteration in GC.It is noteworthy that this copy number gain was significantly associated with increased lymph node metastasis in our gastric adenocarcinoma patients [8].
KLF5 gene (a.k.a. CKLF, IKLF, BTEB2) encodes a member of the Kruppel-like factor subfamily of zinc finger proteins. The protein product acts as a transcriptional activator that specificallybinds directly to a "CACCC"motif in the promoters of various target genes. KLF5 acts downstream of various different signaling pathways and may contribute in both promoting and suppressing cell proliferation. It has been shown that the expression of this gene may be changed in a variety of different cancers and cancer cell lines [9]. Based on our previous finding, in this study we aimed to analyze, for the first time, the possible role of KLF5 mRNA expression in primary gastric tumors and corresponding normal gastric mucosa samples.

\section{PATIENTS and METHODS}

\section{Study Population}

This study was performed in accordance with the principles of the Declaration of Helsinki and was approved by the Research Ethics Committee of Ankara University Faculty of Medicine (approval no: 37-808). A total of 35 newly diagnosed patients with primary gastric adenocarcinoma were included in the current survey. The tissue samples used were obtained from patients who had undergone surgical tumor resection at the Department of Surgical Oncology, Faculty of Medicine, Ankara University, between October, 2004 and January, 2006, after receiving the patients' informed consent granting permission for anonymous use of their tissue samples in future studies.

The patients had no family history of cancer and were free of concurrent malignant conditions other than gastric cancer. None of the patients had received chemotherapy or radiotherapy prior to surgery. If the lesions were considered as early gastric cancer during surgical resection, the patients were excluded from the study. Patients who were diagnosed with diffuse type gastric adenocarcinoma during histopathological evaluation were excluded from the study and only patients with the intestinal type of gastric adenocarcinoma were enrolled. Tumoral and normal mucosa samples were obtained from all the subjects. Samples of normal mucosa were collected from areas near the surgical margins and far from the 
tumors that were macroscopically free of tumor invasion. Only the patients for which RNA samples were available for both tumoral and normal mucosa specimens were included in the present study.

\section{RNA extraction and cDNA synthesis}

RNA samples were obtained from freshly frozen tissue specimens stored at $-80^{\circ} \mathrm{C}$. RNA extraction was performed using Roche TriPure reagent (cat. no. 11667157001; Roche, Mannheim, Germany) according to the manufacturer's instructions. the extracted RNA was quantified using the Spectramax Plus spectrophotometer and SoftmaxPlus v. 4.8 software (Molecular Devices, Sunnyvale, CA, USA).RNAs were converted to cDNA with High Fidelity Transcriptor cDNA synthesis kit (Roche, Germany; Cat. No: 0508995001) following the protocol provided by the manufacturer.Briefly, the reaction mixture were prepared by mixing $100 \mathrm{ng}$ of RNA sample, 2 $\mu \mathrm{l}$ hexamer primer, and $\mathrm{dH}_{2} \mathrm{O}$ to maintain a final volume of $11.4 \mu \mathrm{l}$, and then incubated at $65{ }^{\circ} \mathrm{C}$ for $10 \mathrm{~min}$. After completing the incubation, the reaction mixture was taken on ice and $8.6 \mu \mathrm{l}$ master mix composed of $4 \mu 1$ of $5 \mathrm{X}$ tampon solution $(250 \mathrm{mMTris} / \mathrm{HCl}, 150 \mathrm{mMKCl}, 40$ $\mathrm{mM} \mathrm{MgCl2}, \mathrm{pH} 8.5), 0.5 \mu l$ protector RNase inhibitor (20 mMHepes - KOH, $50 \mathrm{mMKCl}, 8$ mMDithiothreitol, \%50 glycerol, $\mathrm{pH}$ 7.6), $2 \mu \mathrm{l}$ dNTP mixture (10 mM each), $1 \mu l$ Dithiothretiol $(0.1 \mathrm{M})$ and $1.1 \mu 1$ reverse transcriptase (200 mM Potassium Phosphate, 2 mMDithiothretiol, \%0.2 Triton X-100 (V/V), $\% 50$ glycerol, $\mathrm{pH}$ 7.2) was added on reaction mixture. Subsequently, reaction mixture was incubated at $29^{\circ} \mathrm{C}$ for $10 \mathrm{~min}, 48^{\circ} \mathrm{C}$ for $60 \mathrm{~min}$, and $85{ }^{\circ} \mathrm{C}$ for $5 \mathrm{~min}$. Incubations were carried out on the thermocycler (Eppendorf, Germany).

\section{Real-Time qPCR}

KLF5 mRNA expression level was measured by Taq-Man Real-Time qPCR method using Light Cycler 2.0 instrument (Roche, Germany). Glyceraldehyde 3-phosphate dehydrogenase (GAPDH) gene was used as housekeeping gene in order to normalize KLF5 expression level. All the intron spanning primers and TaqMan probes used for expression analysis were designed from "Universal Probe Library" available at www.roche-appliedscience.com/sis/rtpcr/ezhome.html.Primers and probe sequences used to analyze the expression of the KLF-5 gene were Forward: 5'-
CTGCCTCCAGAGGACCTG -3', Reverse: 5'TCGTCTATACTTTTTATGCTCTGGAAT-

3') and UPL prob \#65. Primers and probe sequence used for the analysis of expression of the GAPDH gene were as follows: Forward: 5'ATCATCCCTGCCTCTACTGG-3', Reverse: 5'- GTCAGGTCCACCACTGACAC -3' and Prob: 5'- ACCTTGCCCACAGCCTTGGC- 3'. All the probes used were 5' FAM-, 3' TAMRAlabeled.

Roche Light Cycler TaqMan Master Kit (Roche, Germany; Cat No: 04735536001) was used for PCR reaction preparation. PCR reactions were carried out with a final volume of $20 \mu \mathrm{l}$ containing $4 \mu \mathrm{l}$ master mix (5X enzyme, Fast Start Taq DNA polymerase, reaction tampon, $\mathrm{MgCl}_{2}$, and $\mathrm{dNTP}$ ), $0.5 \mathrm{mM}$ of each primers ( $2 \mu \mathrm{l}$ each), $0.2 \mathrm{mM}$ of probe, $5 \mu \mathrm{l}$ $\mathrm{dH}_{2} \mathrm{O}$, and $5 \mu \mathrm{l}$ of cDNA sample. For each gene, separate PCR reactions were set up in separate capillary. KLF5 and GAPDH expressions of the tissue of interest were analyzed in the same run and no-template control was included in each run. The reaction conditions were as follows: 10 $\min$ at $95^{\circ} \mathrm{C}$ for the pre-incubation step; 55 cycles of $10 \mathrm{~s}$ at $95^{\circ} \mathrm{C}, 30 \mathrm{~s}$ at $60^{\circ} \mathrm{C}$, and $3 \mathrm{~s}$ at $72^{\circ} \mathrm{C}$ for the amplification step, and a final cooling step for $30 \mathrm{~s}$ at $40^{\circ} \mathrm{C}$. Relative gene expression analysis was performed to determine the expression levels of KLF5 gene by using Light Cycler 4.05 software. Fold changes in gene expression levels were calculated by $\Delta \Delta \mathrm{Ct}$ $\left(2^{\wedge}-\Delta \Delta \mathrm{Ct}\right)$ method.

Representative KLF5 and GAPDH amplification curves obtained from normal and tumor samples belonging to the same patient are depicted in Fig. 1A and 1B, respectively.

\section{Statistical Analysis}

Statistical analyses were performed using SPSS (SPSS Inc, Chicago IL, USA) version 15.0. Kaplan-Meier method was used for calculation of DFS and OS. Prognostic factors were analyzed with Cox Regression Model. The cutoff for statistical significance was set at $p$ value $<0.05$.. Difference between relative $K L F 5$ mRNA concentration ratios of the tumor and normal tissues was evaluated by Wilcoxon Signed Ranks test. Relative KLF5 expression in normal and tumor breast tissue and fold changes of KLF5 expression in different clinicopathological groups were analyzed with non-parametric Mann Whitney U or Kruskal Wallis tests. Spearman rho 
coefficient was used for assessing the relation between age and fold change in KLF5expression. Frequencies of $\mathrm{H}$. pylori infection in different clinicopathological groups were compared by Pearson Chi-square test.

Table1.Relationship between KLF5 expression and clinicopathological parameters

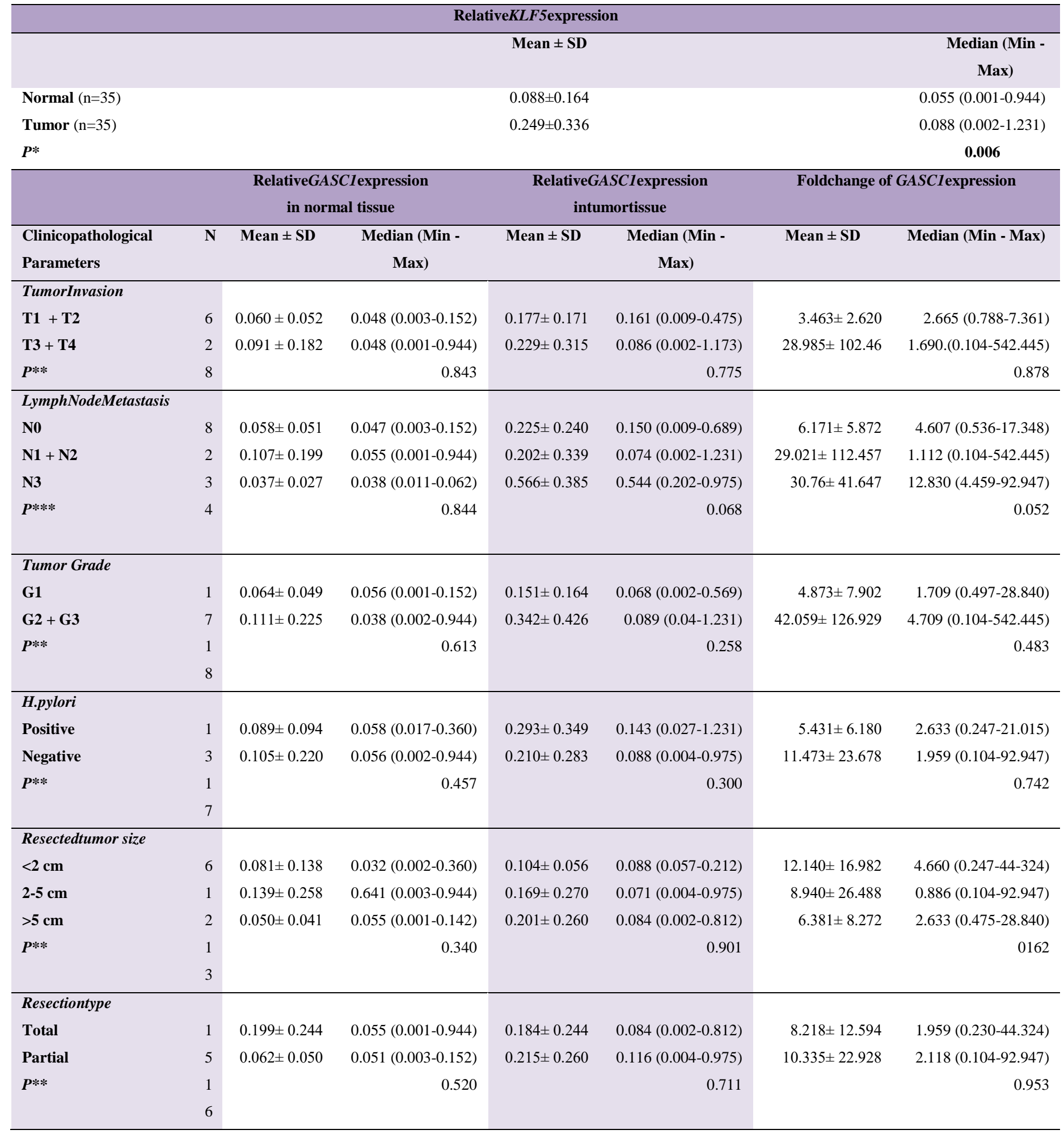




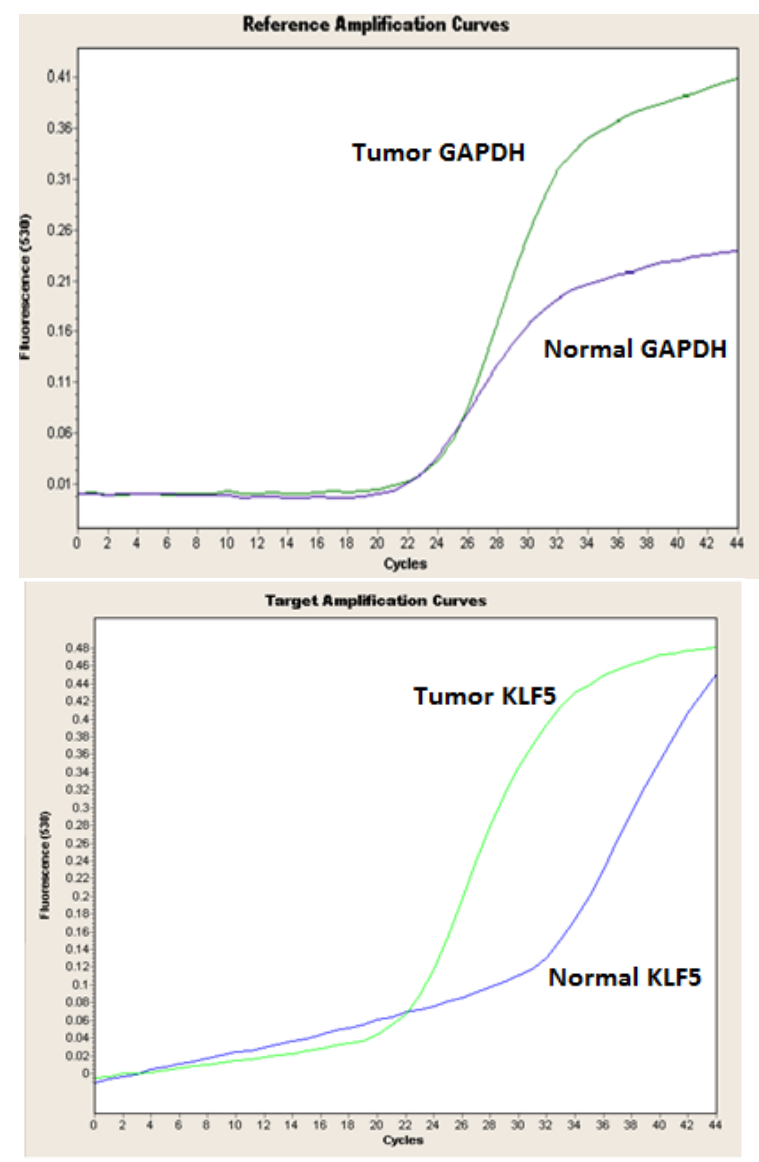

Figure 1.KLF5 (A) and GAPDH (B) gene amplification curves obtained from normal and tumor samples from patient.

\section{Results}

The demographic and clinicopathological characteristics of the patients

Of the patients $23(65.7 \%)$ were male and 12 $(34.3 \%)$ were female with a mean age of 59.45 \pm 10.88 years and $60.55 \pm 14.73$ years, respectively. Histopathological diagnoses were intestinal type adenocarcinoma in all cases. For the tumor invasion, $11.4 \%$ of the patients were designated to be in T1, 8.6\% in T2, 77.1\% in T3, and $2.9 \%$ in $\mathrm{T} 4$ tumor. When the lymph node involvement was investigated, frequency distribution was as follow: N0, 34.3\%; pN1, 25.7\%; pN2, 28.6\%; and $\mathrm{pN} 3,11.4 \%$.The percentages of low-grade (G1), intermediate grade (G2) and high grade (G3) tumor incidences overall were $48.6 \%, 14.3 \%$, and 37.1

Adress for correspondence: Benan Kasapoglu, Dr Abdurrahman Yurtaslan Onkoloji Hastanesi Ankara - Türkiye e-mail: benankasapoglu@ hotmail.com

Available at www.actaoncologicaturcica.com

Copyright $\odot$ Ankara Onkoloji Hastanesi
$\%$, respectively. Only one of the patients had distant metastasis. When the $H$. pylori infection status analyzed, $54.3 \%$ of the patients were found to be H.pylori positive.48.4\% of the patients had undergone total gastrectomy and the remaining had partial resection.
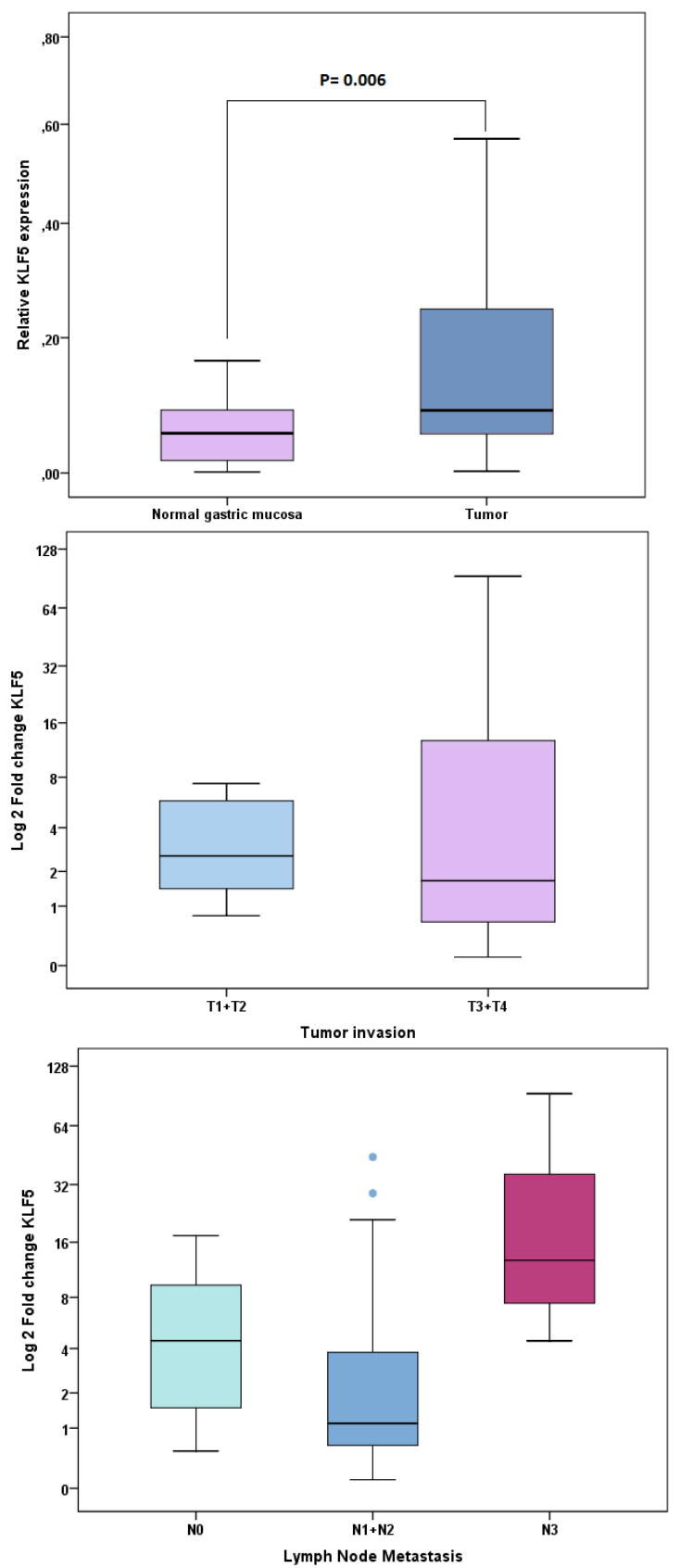

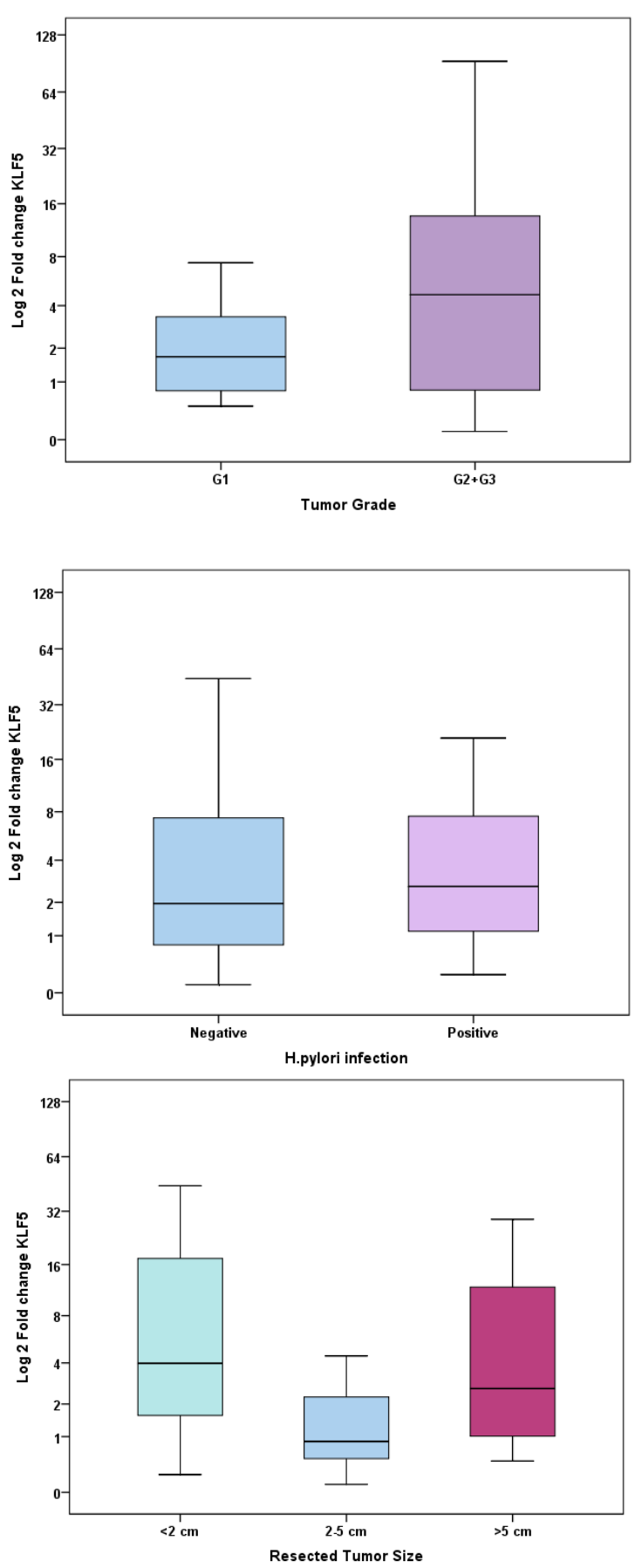

Figure 2. KLF5 expression in different groups. (A) Relative KLF5 expression in normal gastric mucosa and tumor samples. (B) Fold change in KLF5 expression in tumors with different tumor invasion. (C) Fold change in KLF5 expression in tumors with different lymph node metastasis. (D) Fold change in KLF5 expression in tumors with different grade. (E) Fold change in KLF5 expression in tumors with different resection type.

\section{KLF5 mRNA expression}

The extent of KLF5 expression in tumor specimens varied from 0.002 to 1.231 with a mean value of $0.249 \pm 0.336$. In non-tumoral

Adress for correspondence: Benan Kasapoglu, Dr Abdurrahman Yurtaslan Onkoloji Hastanesi Ankara - Türkiye

e-mail: benankasapoglu@ hotmail.com

Available at www.actaoncologicaturcica.com

Copyright $\odot$ Ankara Onkoloji Hastanesi adjacent gastric mucosa the mean KLF5 expression were found as $0.087 \pm 0.164$ ranging from 0.001 to 0.944 (Table 1). Our results showed that KLF5 is overexpressed in tumor tissues than normal gastric mucosa samples $(\mathrm{P}<0.01$, Figure 2A). However, KLF5 expression levels were shown to have significant relation neither with age nor with gender ( $\mathrm{p}>0.05$ ).

\section{Correlation between KLF5 mRNA expression and clinicopathological parameters}

In the present study, we evaluated the correlation between KLF5 expression and the clinicopathological parameters of TNM classification, histological grade, H.pylori infection, resected tumor size, and resection type (Table 1). Since all of the patients exhibited appreciable $K L F 5$ expression in their normal gastric mucosa, we have analyzed KLF5 expression levels both in normal tissues and tumor tissues in terms of any relation with clinicopathological parameters. In addition, fold change of KLF5 expression in tumor tissues compared with their corresponding normal gastric mucosa was also analyzed in this respect.

The association between KLF5 expression and tumor invasion was evaluated for 34 patients. The median $K L F 5$ concentration ratio (minmax) in normal gastric tissue of early stage patients (T1 and T2) and late stage (T3 and T4) patients were $0.048(0.003-0.152)$ and 0.048 (0.001-0.944), respectively, with no statistically significant difference $(\mathrm{P}>0.05)$. Median of KLF5 expressions in tumor tissues with different degree of invasion were found to be similar. Likewise, the fold change of KLF5 expression in $\mathrm{T} 1+\mathrm{T} 2$ tumors have shown no significant difference from $\mathrm{T} 3+\mathrm{T} 4$ tumors ( $\mathrm{P}>0.05$, Figure 2B). Regional lymph node metastasis was also surveyed in relation to $K L F 5$ expression. The median (min-max) KLF5 expression in normal gastric mucosa of the patients with N0 tumors was 0.047 (0.0030.152 ), similarly in patients with $\mathrm{N} 1$ and $\mathrm{N} 2$ tumors was $0.055(0.001-0.944)$ and in patients with N3 was 0.038 (0.011-0.062) ( $\mathrm{P}>0.05)$. Although patients with higher number of lymph node metastases had approximately 5-fold increased KLF5 expression in their tumor tissues than the patients with lower lymph node metastasis, this difference has not reached the statistically significance level $(\mathrm{P}=0.068)$ (Table 
1). Similarly, the fold change of KLF5 expression in patients with different degree of lymph node metastasis were found to be different at a level of limited statistical significance $(\mathrm{P}=0.052)$. Patients with increased lymph node metastasis had KLF5 overexpression when compared to patients with lower lymph node metastasis (Table1, Figure 2C). Due to only one of the patients had distant metastasis, statistical correlation between the KLF5 expression and distant metastasis was overlooked. When the KLF5 expression in normal gastric mucosa of patients with low grade G1 tumors was compared with those of high grade ones $(\mathrm{G} 2+\mathrm{G} 3)$ [0.056 (0.001-0.152) vs $0.038(0.002-0.944)]$ no significant difference was detected $(\mathrm{p}>0.05)$ (Table1, Figure 2D).

The relation between H.pylori infection and different clinicopathological parameters of patients were also analyzed. We have found that the tumors with lower invasion $(\mathrm{T} 1+\mathrm{T} 2)$ had no H.pylori infection and the H.pylori positive samples were all in T3+T4 group $\left(\chi^{2}=\right.$ 5.340; $\mathrm{P}=0.021)$. Similarly, resected tumors greater than $5 \mathrm{~cm}$ were found to be more frequently $H$. pylori infected, although the difference has not reached the statistically significance level $\left(\chi^{2}=3.759 ; \mathrm{P}=0.052\right)$ (Data not shown).

The relative $K L F 5$ expression in normal and tumor tissue, and fold change of KLF5 expression did not show any association with H.pylori positivity $(\mathrm{P}>0.05)$, resected tumor size, and resection type (Table1, Figure 2E).

\section{DISCUSSION}

Despite recent advances in surgical techniques and chemotherapeutic regimens, GC still stands out among the cancer-related deaths worldwide [1]. Over the past years, research-based studies on GC have yielded significant knowledge about the molecular genetic mechanisms underlying this disease. Even, work on the reclassification of gastric tumors based on the molecular changes detected is in progress. In spite of these efforts, the factors related to the prognosis of the disease are still not fully understood [7]. In this study we determined that: KLF5 is overexpressed in tumor tissues compared with normal gastric mucosa samples; although patients with higher number of lymph node metastases had approximately 5-fold increased KLF5 expression in their tumor tissues than the patients with lower lymph node metastasis, the difference was not statistically significant. On the other hand; the relative $K L F 5$ expression in normal and tumor tissue did not show any association with H.pylori positivity.

A hallmark of most solid tumors, including GC, is chromosomal instability that results in gains and losses of genomic material. Among these, copy number variations are commonly reported in GC and these cause to gene expression changes. In our previous work, we have reported DNA copy number changes in 43 patients with gastric adenocarcinomas by using HR-CGH in Turkey. Our most prominent finding was gains of $13 q$ with a minimally overlapping region 13q21-q32, since it has been correlated with an increased lymph node metastasis. In the current study, we have analyzed the expression of KLF5 gene located at $13 \mathrm{q} 21$ region, as possible target for genomic amplification events in gastric cancer.

Up to date, a number of proteins have been identified belonging to the Kruppel-like factor family, which is effective in controlling epithelial homeostasis and carcinogenesis [10]. Kruppel like factors act as DNA-binding transcriptional regulators and participate in the cell proliferation and differentiation [11,12]. KLF4 and KLF5 genes are highly expressed in gastrointestinal epithelial tissue, including esophagus [13]. During embryological development, it was observed that KLF5 is first expressed in primitive intestine at 10th day of development, and afterwards its expression moves towards to intestinal crypts. In the adults, KLF5 is expressed especially at the base of the intestinal crypts, where active cell proliferation occurs [13, 14]. Accumulating evidence based on in vivo studies using the knockout and transgenic animals confirms an important role of KLF5 in embryonic and tissue development via regulating cell proliferation, differentiation, and stemness [9].

The abnormal KLF5 expression has been reported in different types of cancer. A growing body of evidence supports that KLF5 is a critical cancer-related gene [15]. Its' inductive effect on cell proliferation and survival suggest that $K L F 5$ is an oncogene. On the other hand, some studies indicate that KLF5 
might be a tumor suppressor. The promoting role of the KLF5 on cell proliferation has been shown by in vitro cell culture experiments. Nandan et al. [16.17] have reported that KLF5 prevents the contact inhibition and accelerates mitotic entry in H-Ras-transformed NIH 3T3 cells by transcriptionally activating cyclin B1 and Cdc2. In contrast, KLF5 has been implicated to inhibit cell proliferation in several cancer cell lines in vitro. Yann et al. [18] have shown that KLF5 transfected TE2 cells, derived from a patient with poorly differentiated esophageal squamous cancer,

show increased proapoptotic BAX protein after UV irradiation and KLF5 induces both DNA repair and apoptosis . Similarly, Chen et al. [19] reported that KLF5 inhibits colony formation in the DU145 and 22Rv1 prostate cancer cell lines.Important role of KLF5 in cell proliferation and differentiation and its implications for human diseases are well reviewed elsewhere [9].

Deng et al.[20] have reported that KLF5 are frequently amplified in gastric cancer, however, lacking expression studies. Kwak et al.[21] have proposed that KLF5 expression has been reduced in human gastric cancer, which may have been involved in tumor progression because KLF5 expression rate has been high in early-stage gastric cancer and in a small amount of gastric cancer tissues as well as in gastric cancers without lymph node metastasis. Soon et al. [22] have analyzed the expression of $K L F 5$ in gastric cancer and its clinical correlation by immunohistochemical microarray technique. They reported that nuclear staining of the KLF5 expression was significantly associated with a higher tumor grade, higher clinical stage, lymph node status, and 2-year survival, suggesting KLF5 may play an oncogenetic role in gastric carcinogenesis. Similarly, we have found that KLF5 is significantly overexpressed in gastric adenocarcinoma when compared to normal gastric mucosa, confirming our earlier HRCGH results. Aforementioned, our previous findings indicates that gain of $13 \mathrm{q} 21$ is well correlated with increased lymph node metastasis. Although not reached to statistical significance level, our present study shows that increased KLF5 expression is related with increased lymph node metastasis. These results may contribute to expand the role of KLF5 in gastric tumor development and progression.
H.pylori is the strongest known risk factor for the development of gastric cancer. Noto et al. [23] have reported that $H$. pylori induces expression of $K L F 5$ in gastric epithelial cells in vitro and in vivo, and that the degree of $K L F 5$ expression correlated with the severity of premalignant lesions in human gastric carcinogenesis. Although we have found significant relationship between $H$. pylori infection and tumor invasion and tumor size, we could not find any significant effect of H.pylori on $K L F 5$ expression.

It is noteworthy that $K L F 5$ expression has only been studied in tumor tissues. However, as we have shown here, the adjacent normal gastric mucosa also shows appreciable $K L F 5$ expression. In addition, $K L F 5$ expression shows high inter-individual variability in both normal and tumoral tissues, and there is no cut off value of the KLF5 mRNA level to distinguish normal mucosa from tumoral tissue. We suggest that analyzing the KLF5 expression in only tumor tissues may be misleading, therefore, for each patient the fold-change of the KLF5 expression relative to the corresponding normal mucosa tissue should be taken into account when interpreting the association of KLF5 expression with any clinical variable.

There are some limitations of this study that should be mentioned. First, sample size of the 35 patients was relatively small to detect the prognostic significance of the KLF5, despite the significantly increased expression in cancerous tissue. Second, we only measured here the $K L F 5$ expression at the mRNA level and not at the protein level. Further studies with larger sample sizes and additional clinical variables, including disease-free/overall survival rates, are warranted to understand the prognostic value of the KLF5 in gastric carcinogenesis.

In conclusion we determined that; although $K L F 5$ is over-expressed in tumor tissues compared with normal gastric mucosa sample and even though patients with higher number of lymph node metastases had increased KLF5 expression in their tumor tissues than the patients with lower lymph node metastasis, the difference was not statistically significant. We also did not determine any association of KLF5 expression with H.pylori positivity. In that aspect we suggest that: KLF5 expression may have a diagnostic value but not a prognostic worth in patients with gastric cancer. Larger 
studies are warranted to define the exact role of KLF5 expression in gastric cancer.

Acknowledgement: The [DATA TYPE] data used to support the findings of this study are available from the corresponding author upon request.

\section{REFERENCES}

1. Globacan 2012, corp- author. Estimated Cancer Incidence and Mortality Worldwide in 2012.http://globocan.iarc.fr/Pages/online.aspxAcces sed on 28th July, 2017.

2. Stock, M, Otto, F. Gene Deregulation in Gastric Cancer. Gene 2005; 30: 1-19.

3. Baniak N, Senger JL, Ahmed S, Kanthan SC, Kanthan R. Gastricbiomarkers: a globalreview. World J Surg Oncol. 2016; 14: 212.

4. Lauren P. The two histological main types of gastric carcinoma: diffuse and so-called intestinal-type carcinoma. Apmis 1965; 64.1: 31-49.

5. Zheng L, Wang L, Ajani J, Xie E. Molecular basis of gastric cancer development and progression. Gastric Cancer. 2004; 7: 61-77.

6. Yasui W, Sentani K, Sakamoto N, Anami K, Naito Y, Oue N. Molecular pathology of gastric cancer: research and practice. Pathol Res Pract. 2011; 207: 608-12.

7. Lee J, Ou S. Towards the goal of personalized medicine in gastric cancer-time to move beyond HER2 inhibition. Part I: targeting receptor tyrosine kinase gene amplification. Discovery medicine 2013; 15.85: 333-341.

8. Gümüs-Akay G, Unal AE, Elhan AH, et al. DNA copy number changes in gastric adenocarcinomas: high resolution-comparative genomic hybridization study in Turkey. Arch Med Res. 2009; 40(7]:551-60.

9. Dong JT, Chen C. Essentialrole of KLF5transcription factor in cell proliferation and differentiation and its implications for human diseases.Cell Mol Life 2009; 66(16): 2691-706.

10. Ghaleb AM, Nandan MO, Chanchevalap S, Dalton WB, Hisamuddin IM, Yang VW. Krüppel-like factors 4 and 5: the yin and yang regulators of cellular proliferation. Cell Res 2005; 15: 92-96.

11. Shields JM, Christy RJ, Yang VW. Identification and characterization of a gene encoding a gut-enriched Kru"ppel-like factor expressed during growth arrest. J Biol Chem 1996; 271: 20009-20017.
12. Yang Y, Goldstein BG, Nakagawa H, Katz JP. Kru"ppel-like factor 5 activates MEK/ERK signaling via EGFR in primary squamous epithelial cells. FASEB J 2007; 21: 543-550.

13. Conkright MD, Wani MA, Anderson KP, Lingrel JB. A gene encoding an intestinal-enriched member of the Krüppel-like factor family expressed in intestinal epithelial cells. Nucleic Acids Res 1999; 27: 12631270.

14. Ohnishi S, Laub F, Matsumoto $\mathrm{N}$, et al. Developmental expression of the mouse gene coding for the Krüppel-like transcription factor KLF5. Dev Dyn 2000; 217: 421-429.

15. Akhavan-Niaki H, Samadani AA. Molecular insight in gastric cancer induction: an overview of cancer stemness genes. Cell Biochem Biophys. 2014 Apr;68(3):463-73

16. Nandan MO, Chanchevalap S, Dalton WB, Yang VW. Krüppel-like factor 5 promotes mitosis by activating the cyclin B1/Cdc2 complex during oncogenic Ras-mediated transformation. FEBS Lett 2005; 579: 4757-4762.

17. Nandan MO, Yoon HS, Zhao W, Ouko LA, Chanchevalap S, Yang VW. Kruppel-like factor 5 mediates the transforming activity of oncogenic $\mathrm{H}$ Ras. Oncogene 2004; 23: 3404-3413.

18. Yang Y, Goldstein BG, Chao HH, Katz JP. KLF4 and KLF5 regulate proliferation, apoptosis and invasion in esophageal cancer cells. Cancer Biol Ther. 2005; 4(11): 1216-21.

19. Chen C, Bhalala HV, Vessella RL, Dong JT. KLF5 is frequently deleted and down-regulated but rarely mutated in prostate cancer. Prostate 2003; 55: 81-88.

20. Deng N1, Goh LK, Wang H, et al. A comprehensive survey of genomic alterations in gastric cancer reveals systematic patterns of molecular exclusivity and co-occurrence among distinct therapeutic targets. Gut. 2012; 61(5):673-84.

21. Kwak MK, Lee HJ, Hur K, et al. Expression of Kruppel-like factor 5 in human gastric carcinomas. J Cancer Res Clin Oncol 2008; 134:163-167.

22. Soon MS, Hsu LS, Chen CJ, et al. Expression of Krüppel-like factor 5 in gastric cancer and its clinical correlation in Taiwan.Virchows Arch. 2011; 459(2):161-6.

23. Noto JM1, Khizanishvili T, Chaturvedi R, et al. Helicobacter pylori promotes the expression of Krüppel-like factor 5, a mediator of carcinogenesis, in vitro and in vivo. PLoS One. 2013; 8(1):e54344. 